\title{
The improbability of dorso-ventral axis inversion during animal evolution, as presumed by Geoffroy Saint Hilaire
}

\author{
J.A.M. van den Biggelaar ${ }^{1}$, E. Edsinger-Gonzales ${ }^{1,2}$, \& F.R. Schram ${ }^{3}$ \\ ${ }^{1}$ Faculty of Biology, Dept. of Experimental Zoology, University of Utrecht, Padualaan 8, 3584 CH Utrecht, \\ Netherlands, e-mail: JovandenBiggelaar@wanadoo.nl; ${ }^{2}$ Smithsonian Marine Station, Smithsonian Institu- \\ tion, 701 Seaway Drive, Fort Pierce, FL 34949. e-mail: pelagosphera@hotmail.com: ${ }^{3}$ Institute for Biodiver- \\ sity and Ecosystem Dynamics, University of Amsterdam, Mauritskade 57, 1092 AD, Amsterdam, Netherlands, \\ e-mail: schram@science.uva.nl
}

Keywords: amphistomy, axis inversion, deuterostomes, spiral cleavage, protostomes, gastrulation

\begin{abstract}
Recent discoveries in the field of developmental genetics have lead to the resurrection of the old idea, first proposed in the early $19^{\text {th }}$ century, that the dorso-ventral axis of deuterostomes, such as vertebrates, has been inverted during the course of evolution from that noted in protostomes, i.e., what in deuterostomes is dorsal, is in protostomes ventral. However, while attractive in its simplicity, such a suggestion ignores the real events of embryogenesis. During the onset of gastrulation in deuterostomes as well as in protostomes a blastopore is formed with exactly the same embryonic, antero-posterior/dorso-ventral polarity. Subsequent differences in the patterns or morphogenetic movement in gastrulation result in a spatial inversion of this developmental architecture in the adult body plans of protostomes versus deuterostomes. In deuterostomes, the initial anteriorposterior axis is extended more or less evenly while the blastopore remains located posteriorly. In protostomes, such as annelids and gastropods, the growth of the original antero-posterior or animal-vegetal axis is extremely uneven and almost exclusively limited to cells of the embryonic dorsal side. This is coupled with the cells of the original ventral side of the embryo in part moving into the inside of the embryo, and in part moving into what had spatially been the embryonic lateral and more dorsal position. Because of this uneven migration, the embryonic ventral side of the developing larva is not extended and the initial anteroposterior axis is bent, with the blastopore moving into an animal-vegetal position. What were originally dorsal cells move to a ventral position. This fully explains the conservation of developmental gene expression patterns as resulting from a shift of initially dorsally specified cells to a secondarily ventral po-
sition.
\end{abstract}

\section{Contents}

Introduction

Basic embryology 30

Dorso-ventral organization of the blastopore 32

Amphistomy $\quad 32$

A broader perspective $\quad 34$

Acknowledgements 35

References $\quad 35$

\section{Introduction}

In 1822, Geoffroy Saint-Hilaire formulated the hypothesis of a unified body plan throughout the animal kingdom. Being a vertebrate himself, he postulated that all animals would have vertebrae. In vertebrates, the vertebrae are internal, whereas in invertebrates the "vertebrae" were said to be external, as for instance in arthropods where the hypothesized vertebrae are visible as circular cuticular rings. Thus, to Geoffroy Saint-Hilaire arthropods, annelids, and vertebrates could be reduced to the same body plan. However, in contrast to the vertebrates, the dorso-ventral axis of annelids and crustaceans would have had to be inverted such that what is the dorsal surface in deuterostomes is the ventral in protostomes.

The surprising conservation of pattern forming genes between vertebrates and invertebrates has recently revived the discussions of the unity of body plan, including the centuries old idea of dorso-ventral axis inversion (Arendt and Nübler-Jung, 1997; Arendt et al,, 2001; Gerhart, 2001). 


\section{Basic embryology}

In the great majority of the living, bilaterally symmetrical animals, the blastulae have an animal-vegetal polarity. Generally, the animal pole corresponds to the pole where the polar bodies are formed. The cells of the animal hemisphere form the outer epithelial covering of the future adult (cf. Henry et al., 2001), whereas the cells of the opposite veg-

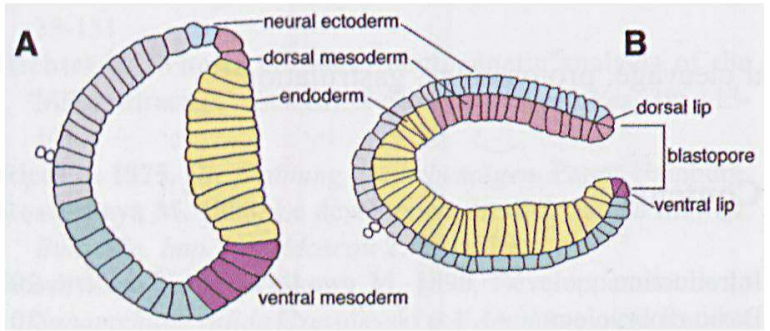

Fig. 1. Median sections of gastrulae in amphioxus; sections are oriented with anterior-posterior axis from left to right anad the doro-ventral axis from top to bottom. A. Young gastrula with initiation of blastopore formation beginning. B. advanced gastrula with posterior blastopore that will become the anus. Note the position of neurogenic ectoderm at the dorsal blastopore lip near the presumptive chorda-mesoderm. (Modified from Nelsen, 1953). etal hemisphere contribute to the development of the central gut tube and the mesoderm.

During gastrulation the cells around the vegetal pole move inside the embryo. Irrespective of the way in which gastrulation occurs, gastrulation itself is common to almost all animals. Thus, it can be assumed that evolution in the embryos of the ancestors of the bilaterians resulted in a process of gastrulation that changed a bipolar blastula (Fig. 1A) into a bipolar gastrula (Fig. 1B) with one opening, the blastopore, at the vegetal pole. This blastopore opening persists and can function either in the formation of the mouth, the anus, or both, or neither.

In the Deuterostomata, the blastopore is formed at the vegetal (posterior) pole of the embryo (Fig. 1A) and is transformed into the anus (Fig. 1B) (cf. Tagawa et al., 2001). In deuterostomes, a mouth opening has to be formed secondarily towards the anterior end of the embryo. In protostomes on the other hand, the initially posterior blastopore (Fig. 2B) eventually becomes the anterior mouth opening (Fig. 3C) due to rotation from the posterior end of the embryo to an anterior-ventral position.

One way to achieve this rotation involves a com-
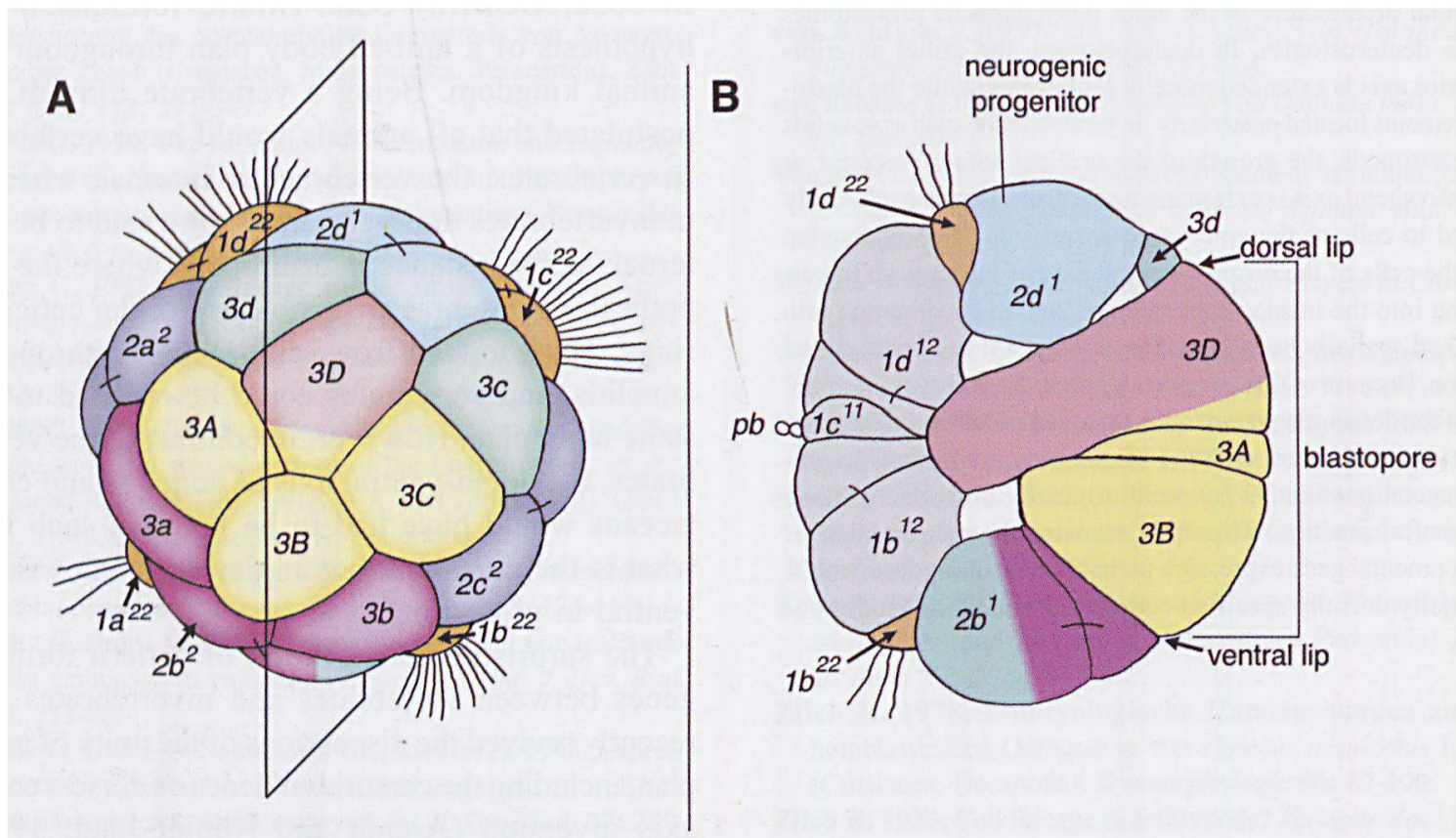

Fig. 2. Blastula of 32-cell stage in Patella vulgata prior to the initiation of gastrulation. A. vegetal view. B. median-section of same as indicated in A. (Modified from van den Biggelaar, 1977; van den Biggelaar and Guerrier, 1979). 


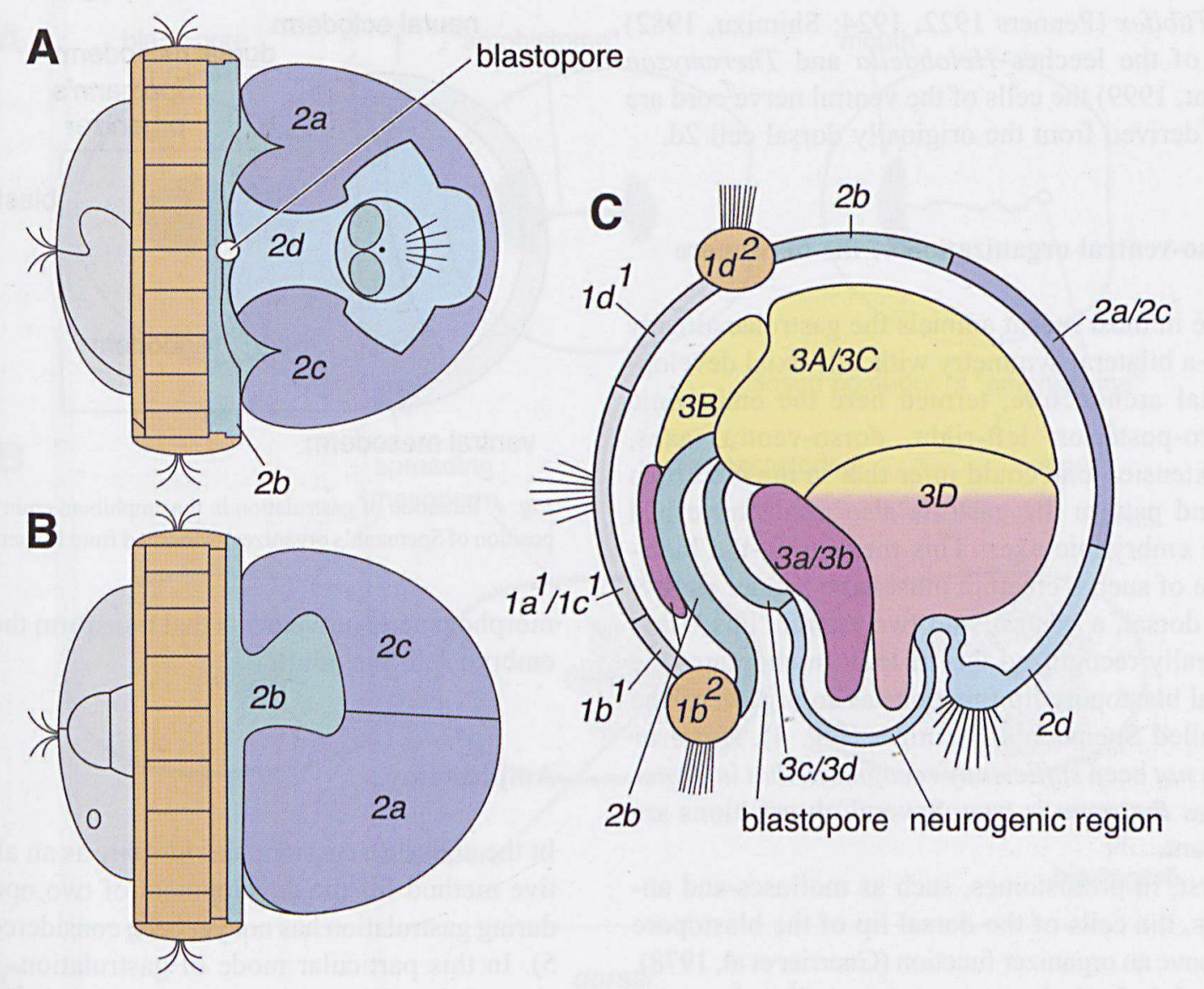

Fig. 3. Schematic drawings of post gastrulation, 24-28 hour trochophore larva of Patella vulgata. Cell lineages marked. Note that the progeny of cell $2 \mathrm{~d}$, which has a dorsal position in the 32-cell stage as shown in Fig. 2, has attained a ventral position in the larva. A. ventral view. B. dorsal view. C. median-section deduced from A and B. (A and B modified from Damen and Dictus, 1997).

plex series of cell movements (Damen and Dictus, 1997). The spatial dynamics of blastopore cell lineages over the course of gastrulation are such that at least in spiralians there is an internalization of B-quadrant midline lineages and a corresponding external migration of the D-quadrant midline lineages to spatially replace them. The more lateral Aand C-quadrant lineages of the blastopore lip pull away, migrate dorsally to occupy, what had been the D-quadrant midline.

The specifics of these migrations involve several steps and can be clearly seen in Patella (Damen, i 994 ). First, derivations of cell $2 \mathrm{~d}$ grow posteriorly and ventrally from their original position on the dorsal side of the embryo (Fig. 3A, C). Second, derivatives of cells $2 b$ (in part), $3 a$, and $3 b$ move internally (Figs. 2B, 3C), and another part of the
$2 \mathrm{~b}$ lineage moves laterally and dorsally (Figs. 2B, 3 ). Third, the derivatives of the macromeres move internally (Figs. 2, 3C). Thus, the ventral midline itself of spiralians, which separates the stomodeum and anus, is derived specifically from the $2 \mathrm{~d}$ lineage, located initially at the embryonic dorsal, Dquadrant, midline of the blastopore lip. As a result of these movements, the blastopore comes to attain an anterior ventral position. Examination of published cell lineage work across the Spiralia (cf. Wilson, 1892; Åkesson, 1967; Anderson, 1966) reveals that morphogenetic transformations are a general feature of spiralian development. In most cases, this results in a bending of the animal-vegetal axis by some 90 degrees, as the vegetal blastopore migrates to an antero-ventral position along the B-quadrant midline. In embryos of the oligocha- 
ete Tubifex (Penners 1922, 1924; Shimizu, 1982) and of the leeches Helobdella and Theremyzon (Stent, 1999) the cells of the ventral nerve cord are also derived from the originally dorsal cell $2 \mathrm{~d}$.

\section{Dorso-ventral organization of the blastopore}

Since in most recent animals the gastrulae already have a bilateral symmetry with a tri-axial developmental architecture, termed here the embryonic antero-posterior, left-right, dorso-ventral axes, by extension one could infer that in the metazoan ground pattern the gastrula also might have had three embryonic axes. This means that the blastopore of such a creature must have had an embryonic dorsal, a ventral, and two lateral "lips." It is generally recognized that at least in chordates the dorsal blastopore lip functions as an organizer, the so-called Spemann's organizer (Fig. 4). However it has not been sufficiently recognized that in protostomes the same is true. Several observations are relevant.

First, in protostomes, such as molluscs and annelids, the cells of the dorsal lip of the blastopore also have an organizer function (Guerrier et al, 1978). Second, in both deuterostome as well as in protostome embryos, MAPK expression is involved in the signaling pathway of the organizer (Lambert and Nagy, 2001). Third, the gene Brachyury is involved in mesoderm formation in all animals (Technau, 2001), especially evident in the dorsal blastopore lip and in the elongation of the posterior body axis. Recently, Arendt et al. (2001) have demonstrated that a Brachyury gene is first expressed in vegetal cells around the closing blastopore of the embryo of the annelid Platynereis dumerilii. In addition, Lartillot et al. (2002) have demonstrated that in the mollusc, Patella vulgata, a Brachyury gene is first expressed on the dorsal side of the blastopore, i.e., in macromere 3D (cf. Fig. 2B). Such strong and homologous dorso-ventral polarity of the blastopore in both deuterostomes and protostomes indicates the initial spatial similarity of protostomes and deuterostomes. The inversion of the expression of dorso-ventral patterning genes in protostomian embryos in comparison with deuterostomian embryos is a result of differences in

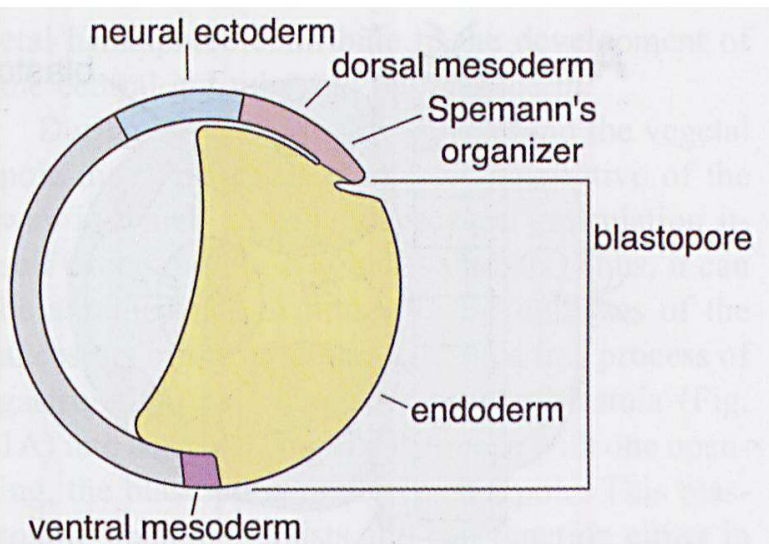

Fig. 4. Initiation of gastrulation in the amphibian embryo, note position of Spemann's organizer. (Modified from Nelsen, 1953).

morphogenetic movements that transform the early embryo into the adult.

\section{Amphistomy}

In the above discussion, amphistomy as an alternative method for the development of two openings during gastrulation has not yet been considered (Fig. 5). In this particular mode of gastrulation, extension of the cells on the "dorsal" side of the early gastrula relocates the blastopore to a "ventral" position. The lateral lips are then said to fuse leaving two openings: an anterior aperture that will become the mouth, and a posterior opening that will become anus. Under this scenario, the blastopore develops into both anal and mouth openings. Such amphistomy is an integral feature of the Trochea Theory (Nielsen, 2001; Nielsen \& Nørrevang, 1985), and is often invoked in molecular considerations of axis inversion (Arendt and Nübler-Jung, 1997). The idea of fusion of the lateral lips of the blastopore, and the formation of the ventral midline by the fused lateral lips, as described by Nielsen (2001) originated from descriptions of the early development of an annelid, Polygordius (Woltereck, 1904), an onychophoran, Peripatopsis (Manton, 1949), a nematode, Pontonema (Malakhov, 1994), and an arthropod, Lucilia (Davis, 1967). Lartillot et al. (2002) also assume an amphistomous gastrulation in the mollusc Patella. We suggest that the amphistomy hypothesis mistakenly derives the protostome 
A
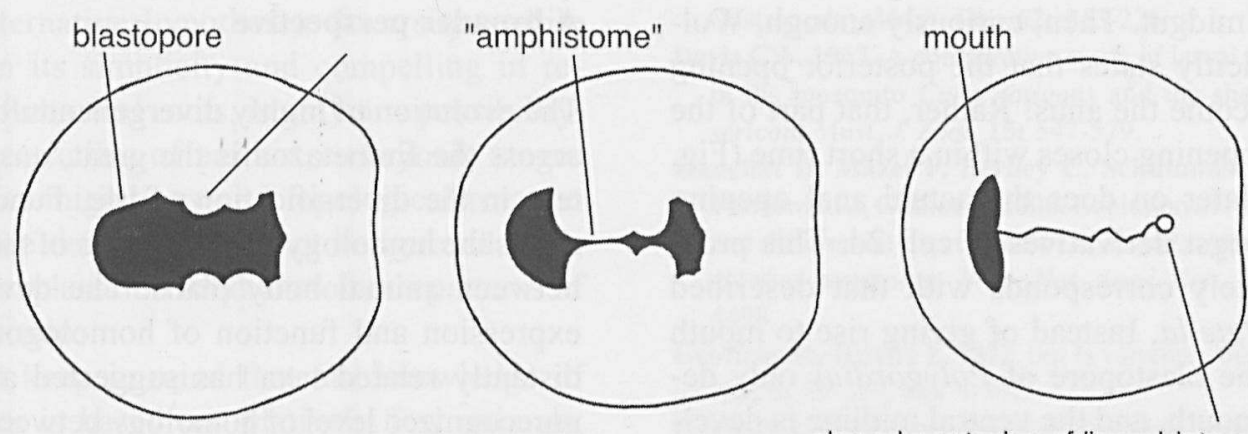

closed posterior of "amphistome"

B

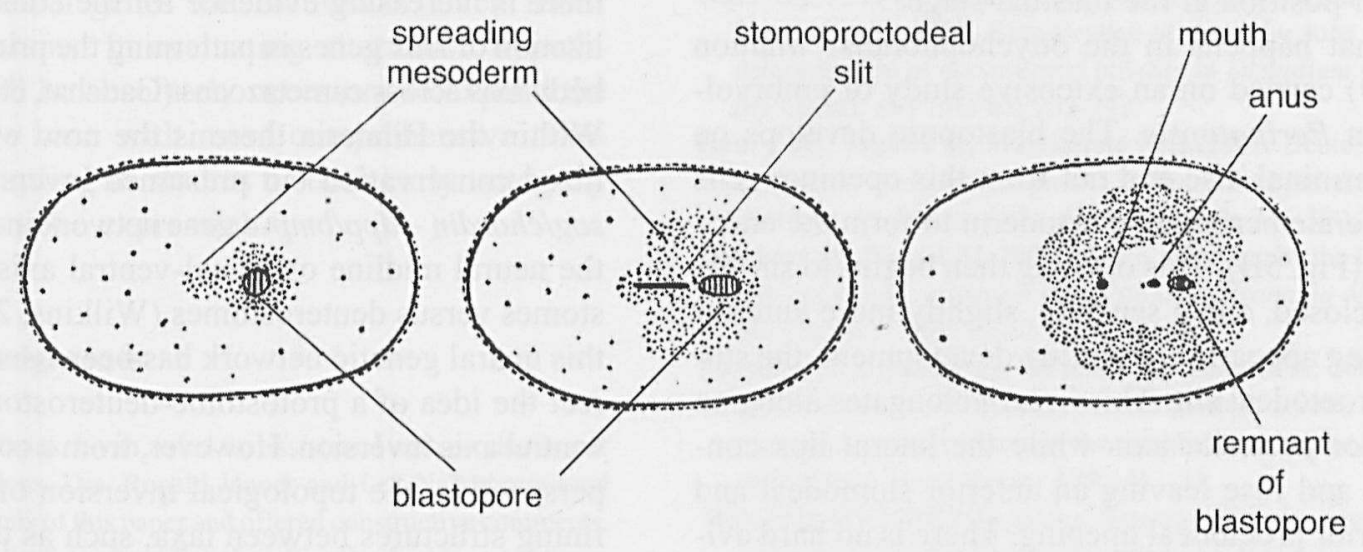

C

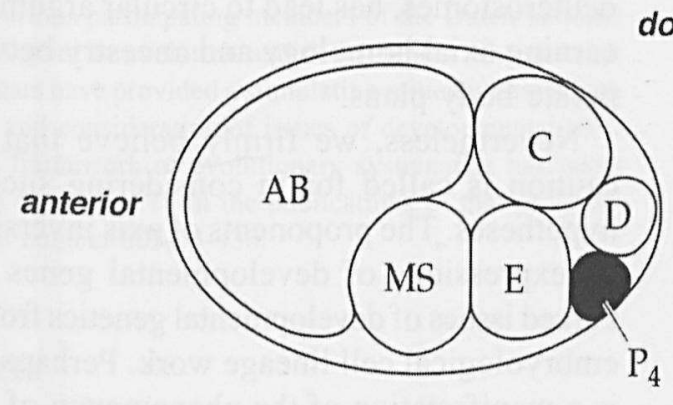

dorsal

ventral

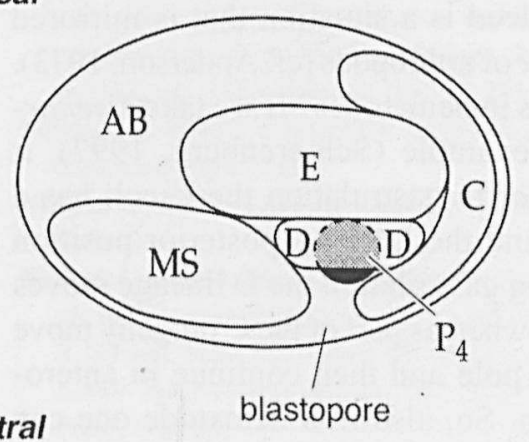

posterior

Fig. 5. Amphistomy. A. sequence of stages of the annelid, Polygordius sp., note that posterior aspect of blastopore closes, only anterior part develops into mouth. (Modified from Nielsen, 2001). B. sequence of stages of Peripatopsis moseleyi, note that as uidstopore closes, a separate stomoproctodeal slit opens anteriorly (Modified from Manton, 1949). C. sequence of stages in cell lineage migration leading up to gastrulation in Caenorhabditis elegans (Modified from Schierenberg, 1997).

ventral midline from cell lineages forming lips of the blastopore at the onset of gastrulation.

What occurs in annelids? In Polygordius, according to Woltereck (1904), the four cells of the fourth quartet of micromeres $4 \mathrm{a}-4 \mathrm{~d}$ have a position at the blastopore. The lateral micromeres $4 \mathrm{a}$ and $4 \mathrm{c}$ grow towards each other (Fig. 5A), by which means the blastopore achieves the form of an hourglass. After both cells have come to touch each other, the blastopore is effectively divided into two openings. The anterior opening becomes the prostoma, which will persist as the mouth opening to the separately 
developing midgut. Then, curiously enough, Woltereck explicitly states that the posterior opening does not become the anus! Rather, that part of the blastopore opening closes within a short time (Fig. 5A). Only later on does the actual anal opening appear amongst derivatives of cell $2 \mathrm{~d}$. This process completely corresponds with that described above for Patella. Instead of giving rise to mouth and anus, the blastopore of Polygordius only develops the mouth, and the ventral midline is developed from derivatives of cell $2 \mathrm{~d}$ that had an original dorsal position at the blastula stage.

What happens in the onychophorans? Manton (1949) carried on an extensive study of embryology in Peripatopsis. The blastopore develops on the germinal disc and out from this opening, cells proliferate beneath the ectoderm to form the endoderm (Fig. 5B). This opening then begins to shrink, or is closed, and a separate, slightly more anterior opening appears later during development, the stomo-proctodeal slit. This in turn elongates along an anterior posterior axis while the lateral lips converge and fuse leaving an anterior stomodeal and posterior proctodeal opening. There is no hard evidence that these two openings correspond with the anterior and posterior openings of the former blastopore. This indeed is a situation that is mirrored in a great number of arthropods (cf. Anderson, 1973).

What happens in nematodes? If we take Caenorhabditis as an example (Schierenberg, 1997), it appears that prior to gastrulation the $\mathbf{C}$ cell has a postero-dorsal and the $\mathrm{D}$ cell a posterior position (Fig. 5C). During gastrulation the $\mathrm{D}$ lineage moves antero-ventrally whereas part of the $\mathrm{C}$ progeny move to the posterior pole and then continue in anteroventral direction. So, also in a nematode one can observe that cells with an original exclusively dorsal position prior to gastrulation later can be found at the ventral side.

Collectively, and despite potential differences in the ultimate fate of the blastopore in different protostome lineages, a closer examination of morphogenesis in protostomes reveals that the ventral midline of the adult is derived from cells with an initially dorsal or dorso-lateral position. Thus the inversion of the dorsal-ventral axis in adult bilaterians can be attributed to differences in morphogenetic transformation of embryo to adult.

\section{A broader perspective}

The evolution of highly divergent adult body plans across the Eumetazoa is the great, unsolved mystery in the diversification of life. Fundamental to this is the homology and evolution of the adult axes between animal body plans. The developmental expression and function of homologous genes in distantly related taxa has suggested a previously unrecognized level of homology between otherwise highly disparate axes and body plans. For instance, there is increasing evidence for the conserved utilization of $H o x$ genes in patterning the primary adult body axis across eumetazoans (Gauchat, et al., 2000). Within the Bilateria there is the now well-recognized conservation but presumed inversion of the sog/chordin - dpp/bmp-4 gene network in patterning the neural midline or dorsal-ventral axis of protostomes versus deuterostomes (Wilkins, 2002), and this neural genetic network has been used to resurrect the idea of a protostome-deuterostome dorsoventral axis inversion. However, from a comparative perspective, the topological inversion of axial-defining structures between taxa, such as the ventral versus dorsal nerve cords of protostomes versus deuterostomes, has lead to circular arguments concerning axial homology and ancestry between disparate body plans.

Nevertheless, we firmly believe that extreme caution is called for in considering such radical hypotheses. The proponents of axis inversion based on expressions of developmental genes have divorced issues of developmental genetics from critical embryological cell lineage work. Perhaps in part it is a manifestation of the phenomenon of the "cutting edge," where "new and modern" research in development gets carried away in its enthusiasm to supplant "old and staid" studies of embryology. Whatever the reason, modern proponents of axis inversion have repeated the mistake of Geoffroy Saint-Hilaire: too much attention is paid to later phases of development at the expense of ignoring information from the earliest stages of ontogeny.

Though the conservation of developmental genes is indeed particularly striking, given the diversity and dissimilarities of bilaterian body plans, interpretation of these expression patterns requires that they be tempered within an operant framework of 
multiple alternative hypotheses. Inversion, while attractive in its simplicity and compelling in regards to its historical roots, is only one possibility. Cell lineage studies of earliest embryonic stages suggests that migrations and topological rotation of micromere derivatives cannot be ignored as an alternative explanation for dichotomous patterns of gene expression.

We must keep in mind that our knowledge of cell lineages is based on relatively few animals, and our examination of patterns of expression of developmental genes has focused on even fewer model systems. In evaluating alternative hypotheses, it will be absolutely necessary to expand the knowledge base with more comprehensive taxonomic sampling in studies of both early ontogeny as well as gene expression.

\section{Acknowledgments}

We wish to thank J. van Arkel for assistance with production of the illustrations. Drs. Ronald Jenner and Lex Nederbragt read earlier versions of this paper and offered constructive comments. In addition, Prof. Gerhard Scholtz offered valuable suggestions towards improving the manuscript. The authors also want to thank the various participating members of the Dutch national research program in evolution and development who through the last 4 years have provided a stimulating milieu within which discussion and consideration of issues of developmental biology in the framework of evolutionary systematics has taken place. This is number 18 in the publications of that program, NWO grant number 805-33-430.

\section{References}

Akesson B. 1967. The embryology of the polychaete Eunice koblensis, Acta Zool. Stockholm 48: 141-192.

Anderson DT. 1966. The comparative embryology of the Polychaeta. Acta Zool. Stockholm 47: 1-41.

Anderson DT. 1973. Embryology and Phylogeny in Annelids and Arthropods. Pergamon Press, Oxford.

Arendt D, Nübler-Jung, K. 1997. Dorsal or ventral: similarities in fate maps and gastrulation patterns in annelids, arthropods, and chordates. Mech. Develop. 61: 7-21.

Arendt D, Technau U, Wittbrodt J. 2001. Evolution of the billaterian larval foregut. Nature 409: 81-85.

Damen P. 1994. Cell-lineage and specification of developmental fate and dorso-ventral organisation in the molluss Patella vulgata. Ph.D. dissertation, Utrecht University.

Damen P, Dietus WJAG. 1997. Cell-lineage and clonal-contribution map of the trochophore of Patella vulagata (Mollusca:
Gastropoda). Mech. Dev. 62: 213-226.

Davis CW. 1967. A comparative study of larval embryogenesis in the mosquito Culex fatigans and the sheep fly Lucilia sericata. Aust. J. Zool. 15: 547-579.

Gauchar $\mathbf{~}$, Mazet $F$, Berney $C$, Schummer $M$, Kreger $s$, Pawlowski J, Galliot B. 2000. Evolution of Antp-class genes and differential expression of Hydra Hox/paraHox genes in anterior patterning. Proc. Nat. Acad. Sci., USA 97: 44934498.

Geoffroy St.-Hillaire E. 1822. Sur la vertèbre. Mém. Mus. d'Hist. Nat. 9: 89-119, Pls. V-VII.

Gerhart J. 2000. Inversion of the chordate body axis: are there alternatives? Proc. Nat. Acad. Sci., USA 97: 4445-4448.

Guerrier P, van den Biggelaar JAM, van Dongen CAM, Verdonk NH. 1978. Significance of the polar lobe for the determination of dorsoventral polarity in Dentalium vulgare (da Costa). Dev Biol 63: 233-242.

Henry JQ, Tagawa K, Martindale MQ. 2001. Deuterostome evolution: early development in the enteropneust hemichordate, Ptyhodera falva. Evol. Devel. 3: 375-390.

Lambert JD, Nagy LM. 2001. MAPK signaling by the D quadrant embryonic organizer of the mollusc Ilyanassa obsoleta. Development 128: 45-56.

Lartillot N, Lespinet O, Vervoort M, Adoutte A. 2002. Expression pattern of Brachyury in the mollusc Patella vulgata suggests a conserved role in the establishment of the AP axis in Bilateria. Development 129:1411-21.

Malakhov VV. 1994. Nematodes. Structure, Development, Classification and Phylogeny. Smithsonian Institution Press, Washington, D. C.

Manton SM. 1949. Studies on the Onychophora VII. The early embryonic stages of Peripatopsis and some general considerations concerning the morphology and phylogeny of the Arthropoda. Phil. Trans. R. Soc. B, 233: 483-580.

Nelsen OE. 1953. Comparative Embryology of the Vertebrates. Blakiston, New York.

Nielsen C. 2001. Animal Evolution. Oxford University Press, Oxford.

Nielsen C, Norrevang A. 1985. The Trochaea theory: an example of life cycle phylogeny. In S.Conway Morris, J.D.George, R.Gibson, Platt H.M. (eds):The Origin and Relationships of Lower Invertebrate Groups, pp. 28-41, Oxford University Press, Oxford.

Penners A. 1922. Die Furchung von Tubifex rivulorum Lam. Zool. Jahrb. Abt. Anat, 43: 323-368.

Penners A. 1924. Die Entwicklung des Keimstreifs und die Organbildung bei Tubifex rivulorum Lam, . ZooL, Jahrb. Abt. Anat, 45: 251-308.

Schierenberg E. 1997. Nematodes, the roundworms. In S.F.Gilbert and A.M.Raunio (eds): Embryology: Constructing the Organism, pp. 313-148. Sinauer, Sunderland.

Shimizu T. 1982. Development of the freshwater oligochaete Tubifex. In F.W. Harrison and R.R. Cowden (eds.): Developmental Biology of Freshwater Invertebrates, pp. 283-316. Alan Liss, New York.

Stent GS. 1999. Introduction to the leech. In SA. Moody (ed.): Cell Lineage and Fate Determination, pp. 173-184. Acad. Press, New York. 
Tagawa K, Satoh N, Humphreys T. 2001. Molecular studies of hemichordate development: a key to understanding the evolution of bilateral animals and chordates. Evol. Devel. 3: 443-454.

Technau U. 2001. Brachyury, the blastopore and the evolution of the mesoderm. BioEssays 23: 788-794.

Wilkins AS. 2002. The Evolution of Developmental pathways. Sinauer Assc., Sunderland.

Wilson EB. 1892. The cell lineage of Nereis. $J_{4}$ Morph $6: 361-$ 480.

Woltereck R. 1904. Beiträge zur praktìschen Analyse der Polygordius Entwicklung nach dem "Nordsee" - und dem
"Mittelmeer" - Typus. I. Die für beide Typen gleichverlaufende Entwicklungsabschnitt: Vom Eỉ bis zum jüngsten Trochophora-Stadium. Arch. EntwMech. Org, 18: 377-403. van den Biggelaar JAM. 1977. Development of dorsoventral polarity and mesentoblast determination in Patella vulagata. J. Morph. 154: 157-186.

van den Biggelaar JAM, Guerrier P. 1979. Dorsoventral polarity and mesoblast determination as concomitant results of cellular interactions in the mollusk Patella vulgata. Dev, Biol 68: 462-471.

Received: 28 August 2002 